\title{
Review
}

Journal of Innate

Immunity
J Innate Immun 2017;9:271-280

DOI: $10.1159 / 000455125$
Received: October 13, 2016

Accepted after revision: December 15, 2016

Published online: February 24, 2017

\section{Innate Lung Defense during Invasive Aspergillosis: New Mechanisms}

\author{
Jaleesa M. Garth Chad Steele \\ Department of Medicine, University of Alabama at Birmingham, Birmingham, AL, USA
}

\author{
Keywords \\ Innate immunity · Aspergillus fumigatus · Pattern \\ recognition receptors . Cytokines
}

\begin{abstract}
Invasive aspergillosis (IA) is one of the most difficult to treat and, consequently, one of the most lethal fungal infections known to man. Continued use of immunosuppressive agents during chemotherapy and organ transplantation often leads to the development of neutropenia, the primary risk factor for IA. However, IA is also becoming more appreciated in chronic diseases associated with corticosteroid therapy. The innate immune response to Aspergillus fumigatus, the primary agent in IA, plays a pivotal role in the recognition and elimination of organisms from the pulmonary system. This review highlights recent findings about innate host defense mechanisms, including novel aspects of innate cellular immunity and pathogen recognition, and the inflammatory mediators that control infection with $A$. fumigatus.
\end{abstract}

(C) 2017 S. Karger AG, Basel

\section{Introduction}

Concerns are mounting over the rise in invasive fungal infections (IFIs) caused by Candida, Cryptococcus, and Aspergillus species over the last several decades due to modern medical interventions, such as immunosuppressive drugs. IFI caused by Aspergillus fumigatus, i.e., inva- sive aspergillosis (IA), remains one of the most lethal human infectious diseases. Development of IA may be the result of multiple predisposing factors, but immunosuppression leading to neutropenia remains the predominant risk factor $[1,2]$. Solid-organ transplantation (approx. 30,000/year in the USA) and hematological malignancy, primarily acute myeloid leukemia and acute lymphoblastic leukemia requiring stem-cell transplantation (approx. 20,000/year in the USA), are the greatest risk factors for the development of IA [3]. The most recent data from the Transplant-Associated Infections Surveillance Network reflect an IFI incidence rate of $7 \%$ in both solid-organ [4] (19\% due to IA) and stem-cell [5] ( $43 \%$ due to IA) transplantation. IA is particularly common in lung transplantation, where it is associated with $>70 \%$ of IFIs [6]. ICU patients represent a newly appreciated and significant at-risk population for IA. These patients often present with exacerbations of chronic obstructive pulmonary disease, alcoholic liver cirrhosis, and solid cancers. High-dose corticosteroid usage is a frequent comorbidity, and inhospital mortality can range from 46 to $79 \%$ [7-10].

\section{Cellular Effectors}

\section{Neutrophils}

Neutrophils have long been appreciated as the essential cell type for eliminating A. fumigatus, and neutropenia remains the primary risk factor for developing inva-

\section{KARGER}

(c) 2017 S. Karger AG, Basel

E-Mail karger@karger.com

www.karger.com/jin
Dr. Chad Steele

Department of Medicine, University of Alabama at Birmingham 1900 University Blvd, THT 437A

Birmingham, AL 35294 (USA)

E-Mail chadsteele@uab.edu 
sive aspergillosis. Consequently, neutrophils continue to be a focus of investigation. Previous studies suggested that neutrophils were primarily effective against hyphae rather than conidia [11], although recent data challenge this assertion. Investigating neutrophils from individuals with a variety of defects in innate immune genes has revealed that neutrophil-mediated recognition of conidia requires $\mathrm{CD} 11 \mathrm{~b} / \mathrm{CD} 18$ (e.g., complement receptor 3) rather than Dectin-1. Conversely, hyphal recognition requires antibody-mediated opsonization and $\mathrm{Fc} \gamma$ receptors [12]. Mechanistically, the killing of A. fumigatus hyphae by neutrophils requires both NADPH oxidase and myeloperoxidase, but not the formation of neutrophil extracellular traps (NETs). In contrast, the killing of conidia is achieved by nonoxidative lactoferrin-mediated iron sequestration. An additional study has recently examined interactions between human neutrophils and A. fumigatus conidia and hyphae in the presence of various chemoattractants and neutrophil activators [13]. Using a nanoliter culture well system, this study demonstrated that less than a third of conidia form hyphae when incubated with pure neutrophils, an amount that continues to decrease when the cocultures contain a uniform amount of leukotriene B4, but not fMLP. In contrast, using a chemotaxis chamber, unprimed neutrophils reduce hyphal formation by approximately $50 \%$ whereas the addition of fMLP or leukotriene B4 gradients increases neutrophil chemotaxis and a more rapid phagocytosis of conidia, with leukotriene B4 demonstrating superior neutrophil priming compared to fMLP. Neutrophils from patients undergoing immunosuppressive therapy are less effective at limiting hyphal transformation and appear less responsive to fMLP stimulation.

Neutrophils express multiple pattern recognition receptors (PRRs) involved in A. fumigatus recognition, including the $\beta$-glucan receptors Dectin-1 and Mac-1 (CR3). Although studied with the fungal particle zymosan or the pathogenic fungal organism Candida albicans, it was recently reported that Dectin- 1 and Mac- 1 induced the expression of protein kinase $C \gamma$ in neutrophils [14]. Neutrophils from mice deficient in protein kinase $C \gamma$ have impaired reactive oxygen species (ROS) generation, granule content release, cytokine production, and killing of $C$. albicans. Upon fungal exposure, protein kinase $\mathrm{C} \gamma$ mice were unable to clear a systemic (C. albicans) or pulmonary (A. fumigatus) challenge, indicating that protein kinase $\mathrm{C} \gamma$ has a central role in regulating the degradative and microbicidal properties of neutrophils required for fungal clearance [14].
Previous studies documented an interesting, yet unexpected role for neutrophils in regulating the number of inflammatory dendritic cells (DCs) in the lung during A. fumigatus exposure [15]. A recent follow-up to this study determined that DCs recruited in the absence of neutrophils display a more immature phenotype [16]. In fact, when neutrophils are cocultured with DCs, an increase in costimulatory molecule expression occurs, a process that requires the C-type lectin receptor, DC-SIGN. Another intriguing study recently characterized the spatiotemporal recruitment (examined at 4,16 , and $40 \mathrm{~h}$ after challenge) of neutrophils and other innate cells to the lung in 2 different murine models of immunosuppression-associated IA, i.e., mice receiving cyclophosphamide + cortisone treatment (CCT) or corticosteroid treatment (CT) [17]. The CCT model demonstrated earlier mortality $(100 \%$ within 4 days) and showed a profound reduction in the neutrophil and macrophage populations in the lung with $4 \mathrm{~h}$ of exposure. In contrast, despite demonstrating 100\% mortality within 7 days, the CT model demonstrated increased neutrophil and macrophage recruitment to the lung with $4 \mathrm{~h}$ of exposure, but blunted the DC and monocyte recruitment. Adoptive transfer of bulk CD11b+ myeloid cells to mice treated with cyclophosphamide alone, but not to CCT mice, protected against IA.

The concept of "trained immunity" was previously reported in a model of systemic candidiasis, whereby a nonlethal exposure subsequently protected mice against a lethal exposure, which was due to the Dectin-1-dependent epigenetic reprogramming of monocytes [18]. This phenomenon has recently been reported with A. fumigatus lung exposure; exposing mice deficient in T, B, and natural killer cells to a nonlethal inoculum subsequently protected mice against a lethal exposure [19]. Mechanistically, neutrophils and macrophages were recruited in higher numbers, expressed higher levels of Dectin-1 and CXCR2, and produced early or higher amounts of specific inflammatory cytokines, including IL- $1 \alpha$, IL-1 $1 \beta$, GCSF, TNF- $\alpha$, IL-6, and IL-17A.

\section{Macrophages, Inflammatory Monocytes, Eosinophils,} and Natural Killer T Cells

As detailed above, it has long been recognized that neutrophils are essential for defense against IA. However, the innate immune response to A. fumigatus in the lung involves the recruitment and/or participation of numerous cell types. Alveolar macrophages have long been recognized as effector cells against $A$. fumigatus. A recent study has shown that this cell type controls the majority of fungal germination [20]. However, some organisms es- 
cape the late phagosome and are laterally transferred to other macrophages. Intriguingly, the calcineurin inhibitor FK506 reduces macrophage death and lateral transfer, which results in uncontrolled fungal germination in macrophages. An additional innate cell type recently studied in A. fumigatus control is the CCR $2+$ inflammatory monocyte [20]. These cells are thought to function in transporting fungal antigens from the lung to the draining lymph node, where they prime CD4 T cell responses. Subsequently, a study examining the effects of depleting CCR2+ inflammatory monocytes revealed that these cells are as essential as neutrophils for controlling lung fungal burden [21]. Depleting CCR2+ inflammatory monocytes did not impact chemokine production, neutrophil recruitment after A. fumigatus exposure, or neutrophil uptake of conidia. However, neutrophils from mice depleted of CCR2 + inflammatory monocytes were less effective at killing A. fumigatus conidia, both in vitro and in vivo, presumably as a result of the impaired production of cytokines (TNF- $\alpha$ ) and effector molecules (pentraxin 3 [PTX3]) that enhance neutrophil antifungal activity. In addition, CCR2+ inflammatory monocytes themselves possessed the ability to kill $A$. fumigatus.

The presence of eosinophils has been documented in multiple diseases caused by A. fumigatus, including IA [22]. Despite low numbers of eosinophils in the lung after A. fumigatus exposure, we have reported that mice deficient in eosinophils demonstrate delayed fungal clearance in the presence of germinating organisms in the lung [22]. Despite blunted proinflammatory cytokine and chemokine levels, there are no defects in innate cell recruitment to the lungs of eosinophil-deficient mice, which suggests that eosinophils themselves must function in $A$. fumigatus killing. Indeed, pure eosinophils inhibit the growth of A. fumigatus in vitro, a process that does not require cell contact and can be duplicated by eosinophil cell lysates.

A previous study reported that mice deficient in natural killer T (NKT) cells had delayed clearance of $A$. $f u-$ migatus from the lungs [23]. Mechanistically, this report demonstrated that Dectin-1- and MyD88-dependent responses promoted IL-12 production by DCs that drove NKT cells to secrete interferon (IFN)- $\gamma$. Building upon this observation, human NKT cells were examined for their response to distinct fungal morphotypes and DCs [24]. It was shown that CD1d+CD1c+ myeloid DCs were the most potent activator of NKT cells. When live $A$. $f u$ migatus was employed, NKT cells had reduced expression of TNF- $\alpha$, G-CSF, and RANTES, but not of type 1 or type 2 cytokines.

Innate Defense against Aspergillus

\section{Membrane-Bound and Soluble Receptors}

\section{Toll-Like Receptors}

Toll-like receptors (TLRs) are type 1 membrane receptors in a superfamily of 13 transmembrane proteins; 10 are expressed in humans, and 6 of these have been implicated in the recognition of A. fumigatus. Many experimental studies have investigated the role of TLRs in IA defense and this will therefore not be discussed in detail here. Regarding immunogenetics, TLR1, TLR6 (coreceptors for TLR2), and TLR4 were the first TLRs recognized as having a genetic susceptibility to IA $[25,26]$. Recent studies have uncovered surprising roles for TLR3, which senses RNA, and TLR5, which senses bacterial flagellin, in susceptibility to IA. Mice deficient in TLR3 demonstrate impaired lung fungal clearance which correlates with defective CCR7+ DC migration to the lymph nodes and impaired CD $8 \mathrm{~T}$ cell responsiveness [27]. Moreover, polymorphisms in TLR3 increase the risk of IA after hematopoietic stem cell transplantation, with these individuals demonstrating impaired IFN-1 and CD8 T cell responses to A. fumigatus RNA [27]. Regarding TLR5, although the A. fumigatus ligand putatively recognized by TLR5 is not known, in vitro genetic knockdown studies implicated a role for TLR5 in A. fumigatus killing [28]. Subsequently, a TLR5 stop single-nucleotide polymorphism (SNP) was identified as an independent risk factor for IA in recipients after allogenic hematopoietic stem cell transplantation [29]. Finally, although the significance of this observation in IA has yet to be determined, a recent study implicated TLR10, which has no known ligand to date, in chronic cavitary pulmonary aspergillosis [30].

Chitin is a major component of the A. fumigatus cell wall, and is usually unmasked when organisms germinate. The PRR for chitin has not been conclusively identified, although TLR2, TLR9, and NOD2 have been implicated as the chitin PRRs in mice, where it drives the production of IL-10 [31]. In human peripheral blood mononuclear cells, chitin purified from the A. fumigatus cell wall was recently shown to induce the anti-inflammatory factor IL-1RA, but not the proinflammatory cytokines IL- $1 \beta$, TNF- $\alpha$, IL- 6 , or IL-8 [32]. In vitro blocking studies revealed that Dectin-1, TLR2, TLR4, the mannose receptor and NOD2 were not involved in the production of IL-1RA. In contrast, chitin-induced IL-1RA production requires the presence of immunoglobulins and Fc$\gamma$ RII. However, IgG-opsonized chitin is able to synergistically induce IL- $1 \beta$ production when combined with the ligands for TLR2, TLR4, and NOD2, but not the Dectin-1 ligand. 


\section{C-Type Lectin Receptors}

The C-type lectin-like receptor Dectin-1 has been extensively studied in host defense against A. fumigatus, with deficiency in Dectin-1 in humans and susceptibility to IA having been described. Newer findings regarding Dectin-1 in immune responsiveness to A. fumigatus include the observation that Dectin-1 expression is induced in human bronchial epithelial cells in a TLR2-dependent manner, where it promotes the production of inflammatory mediators and antimicrobial peptides [33]. Although NETs have been reported as an antifungal effector mechanism against $A$. fumigatus, a recent study showed that NETs are only formed when A. fumigatus is clumped in large aggregates or else in the presence of $A$. fumigatus hyphae [34], thereby contradicting the study on human neutrophils that we mentioned earlier [12]. Intriguingly, Dectin-1 functioned as a negative regulator of NETosis, as NET formation was enhanced in the absence of Dectin-1 and resulted in more tissue damage. Myeloid-derived suppressor cells (MDSCs) are neutrophil-like cells that function to regulate immune responses, often at the level of T cells. A recent study identified the induction of MDSCs in both mice and humans in response to $A$. $f u$ migatus [35]. Subsequently, using cells from humans and mice deficient in Dectin-1 revealed a requirement for Dectin-1 in the development of MDSCs during A. fumigatus infection [35].

Dectin-2 is another C-type lectin-like receptor that, unlike Dectin-1, has specificity for fungal mannans. Although not extensively studied in the context of $A$. $f u$ migatus infection, a recent study reported that the cytokines IL- 6 and IL-23 induce the expression of the IL-17 receptor IL-17RC on human and mouse neutrophils [36]. Dectin- 2 expression is also induced by IL- 6 and IL-23 and, when stimulated with an A. fumigatus hyphal extract, promotes higher IL-17RC expression, leading to IL-17A-mediated ROS induction and subsequent fungal killing [36]. Likewise, plasmacytoid DCs express Dectin-2 and, upon A. fumigatus hyphal recognition, produce inflammatory and type 1 IFN responses as well as form structures that resemble NETs [37].

\section{Pentraxin 3}

Early studies revealed a novel, nonredundant role for the long pentraxin, PTX3, in innate defense mediated by alveolar macrophages and neutrophils during IA. The importance of PTX3 in IA defense has now been validated clinically, as a homozygous haplotype in PTX3 was found to be associated with an increased risk of IA in an investigative and validation cohort [38]. This haplotype resulted in defective expression of PTX3 in neutrophils, leading to impaired phagocytosis and clearance of A. fumigatus. As detailed earlier, TLR4 is recognized as an important PRR in IA defense. PTX3 was recently identified as binding to myeloid differentiation protein 2 (MD-2) in vitro and mediating antifungal activity in vivo via TLR4/MD-2-mediated signaling [39]; mechanistically, the engagement of MD-2 by PTX3-opsonized $A$. fumigatus activated a TRIFmediated IFN- $\beta$-dependent signaling pathway. Immunosuppression with drugs such as cyclosporine A or tacrolimus is commonly associated with a higher incidence of IA. A recent study has discovered a mechanism behind this immunosuppression, i.e., targeting the calcineurinNFAT binding pathways suppresses the expression of PTX3, which leads to increased susceptibility to IA [40].

\section{Ficolins}

Ficolins are soluble, secreted PRRs that function to activate the lectin complement pathway. Three different ficolins exist in humans, ficolin-1 (FCN-1/M-ficolin), ficolin-2 (FCN-2/L-ficolin), and ficolin-3 (FCN-3/H-ficolin), while mice only possess an ortholog of human FCN-2, termed ficolin-A. Initial studies demonstrated that although ficolin-A opsonized A. fumigatus and had enhanced binding to human lung epithelial cells, ficolin-Aopsonized conidia did not lead to lectin pathway-specific C4 deposition [41]. Ficolin-A opsonized A. fumigatus did, however, augment human lung epithelial cell IL-8 production. In contrast, ficolin-A opsonized A. fumigatus dampened the production of IL- $1 \beta$, IL- 6 , and TNF- $\alpha$ by human monocyte-derived macrophages and neutrophils, despite enhancing their antifungal activity [42]. Similar results have been reported for L-ficolin [43] and $\mathrm{H}$-ficolin [44], both of which were found to be elevated in bronchial lavage fluid from lung-transplant recipients with documented A. fumigatus infection. The role of ficolins in vivo has also recently been reported, whereby mice deficient in ficolin-A experience delayed clearance of $A$. $f u$ migatus from the lungs. However, the mechanism involved is not associated with defective complement activation but rather the impaired induction of inflammatory mediators such as IL- $1 \beta$ [45].

\section{Effector Cytokines}

\section{IL-1 Family}

The IL-1 family of cytokines comprises 11 members, 7 with proinflammatory characteristics (IL- $1 \alpha$, IL-1 $\beta$, IL18 , IL-33, IL-36 $\alpha$, IL-36 $\beta$, and IL-36 $\gamma$ ) and 4 with putative 
anti-inflammatory characteristics (IL-1Ra, IL-36Ra, IL37, and IL-38). Surprisingly, the initial study examining IL-1 signaling in IA defense did not identify a protective role [46]. However, this phenotype may be the result of a compensatory increase in IFN- $\gamma$ production. There has been renewed interest in the role that IL- $1 \alpha$ and IL- $1 \beta$ play in immune defense, with a recent study challenging the negative role for IL-1R during IA [47]; it demonstrated that IL-1R was essential for survival, with IL-1 $\alpha$ promoting leukocyte recruitment and IL- $1 \beta$ promoting antifungal activity. This study was different from the previous one regarding organism inoculum, dosing strategy, and the model of IA. A subsequent study examined various inflammasome components in the protection against IA [48]. Here, using the CCT model of immunosuppressionassociated IA, mice individually deficient in NLPR3 or AIM2 were not more susceptible that wild-type mice. However, susceptibility was enhanced with combined NLPR3 + AIM2 deficiency ( $80 \%$ mortality by day 15$)$, ASC deficiency ( $90 \%$ mortality by day 15$)$, and dual caspase $1+$ caspase 11 deficiency (100\% mortality by day 6$)$. DCs from combined NLPR3 + AIM2 deficiency demonstrated impaired IL- $1 \beta$ and IL- 18 production in response to A. fumigatus when compared to mice deficient in a single agent. Likewise, similar to the observation above, mice deficient in IL- $1 \beta$ demonstrated decreased survival (75 vs. $25 \%$ mortality in wild-type mice by day 15 ).

Despite a clear protective role for IL-1R signaling in IA defense, excessive IL-1R signaling may be detrimental. Excessive inflammation observed during IA in chronic granulomatous disease (CGD) is IL-1-dependent and can be ameliorated by IL-1R blockade [49]. Similarly, studies have shown that NLRP3 inflammasome-mediated responses during A. fumigatus exposure in murine and human cystic fibrosis (CF) is a result of defective IL-1RA production, which can be minimized by treating with anakinra (recombinant IL-1RA) [50]. Collectively, while IL-1R signaling is essential for the elimination of $A$. $f u$ migatus from the lungs, in specific inflammatory conditions such as CGD and CF, IL-1R signaling rather serves as a therapeutic target for inhibition.

The IL-36 isoforms IL-36 $\alpha$, IL-36 $\beta$, and IL-36 $\gamma$ are expressed by epithelial cells and monocytes and binds the receptor and coreceptor complex of IL-1Rrp2/IL-1RAcP where they induce proinflammatory responses and antimicrobial factors. The contribution of IL-36 isoforms on T helper responses to A. fumigatus has been recently described in humans. Results showed morphologic specific induction of IL-36 $\alpha$ and IL-36 $\gamma$, which was dependent on Dectin-1, Syk and TLR4, yet regulated by TLR2 and CR3.
Inhibition of IL-36R resulted in attenuated IL-17 and IFN- $\gamma$ production in response to A. fumigatus [51]. IL-37 is anti-inflammatory cytokine of the IL-1 family that binds IL-18R. Treating A. fumigatus infected mice with IL-37 results in inhibition of NLRP3 inflammasome-generated IL- $1 \beta$ secretion, which was dependent on the IL-1 family decoy receptor TIR-8/SIGIRR [52].

\section{IL-17A, IL-22, and GM-CSF}

We and other study groups have reported an important role for IL-17A in lung defense against $A$. fumigatus. Recent studies have now extended this role to the eye, as neutrophils have been identified as a critical source of IL17A during fungal keratitis [53]. Assessment of JAK/ STAT pathway inhibition in this model was shown to have a negative effect on ROS production and fungal killing activity, but also blocked the activity of elastase and gelatinase that is associated with tissue damage [54]. CD4 and $\gamma \delta$ T cells may also produce IL-17A after A. fumigatus challenge. Sublethal A. fumigatus exposure has also been employed to assess the role of DC subsets in generating Th17, specifically documenting an IRF4-dependent $\mathrm{CD} 11 \mathrm{~b}+\mathrm{CD} 24+\mathrm{CD} 64-\mathrm{DC}$ population in mucosal tissues with functional specialization to instruct IL-17 responses during fungal infection [55].

We have previously reported a protective role for IL22 in lung defense against $A$. fumigatus [56], and also that IL-22 contributes to immunopathogenesis in a model of fungal asthma [57]. In the latter study, we reported that CD4 T cells were a significant source of Dectin-1-dependent IL-17A, with IL-22 being produced at much lower levels. However, another study has shown that, in human peripheral blood mononuclear cells, heat-inactivated $A$. fumigatus conidia and hyphae induce high levels of IL-22, primarily in CD4 T cells, although CD8 T cells and NKT cells also serve as an IL-22 cell source [58]. Intriguingly, $10 \%$ of the IL-22 produced in these cultures was by an unidentified cell source. Similarly, individuals with CF, who are often colonized with multiple microorganisms, including A. fumigatus, demonstrate increased levels of CD4 T cells that produce both IL-17A and IL-22 [59].

GM-CSF has been implicated in the defense against multiple fungal organisms, but its role in A. fumigatus lung defense has yet to be characterized. Recently, it was demonstrated that mice deficient in the receptor for GMCSF were unable to control infection, primarily as a result of the recruitment of inflammatory monocytes being impaired, but not that of neutrophils. However, the defective generation of ROS and also antifungal activity was exhibited by both cell types [60]. GM-CSF treatment was 
found to be effective in enhancing neutrophil function and lowering the A. fumigatus lung burden, an effect dependent on the generation of ROS.

\section{Processes Affecting Innate Immunity}

\section{Autophagy}

Autophagy is a lysosomal degradation pathway described as mediating the clearance of multiple pathogens via their engulfment upon escape to the cytosol. Although A. fumigatus-associated PRRs expressed on the cell surface are relatively well-characterized, less is known about those expressed in the phagolysosome. However, we have previously reported that innate recognition of ingested resting A. fumigatus conidia is mediated by Dectin-1 in acidified phagolysosomes following conidial swelling [61]. This process was recently identified in human monocytes, where Dectin-1-mediated $\beta$-glucan recognition of A. fumigatus was required for the selective recruitment of LC3 II autophagy proteins [62]. Induction of autophagy was required for organism killing, as the inhibitionofATG5autophagyproteinsimpaired phagolysosome fusion. Interestingly, abolishing ROS induction or employing monocytes from CDG patients failed to induce LC3+ phagosome formation following infection with $A$. fumigatus. A similar observation was made when examining monocytes from patients after the administration of corticosteroids. In a follow-up study, it was found that, in addition to $\beta$-glucan recognition for LC3 phagolysosome formation, cell wall resolution of melanin is also required [63]. It demonstrated that melanin found in the $A$. $f u$ migatus cell wall, while potently inducing proinflammatory cytokine production, failed to induce ROS production in human monocytes as a result of specific inhibition of the interaction between the p22phox subunit of flavocytochrome b558 with the NADPH oxidase complex. Importantly, in the aforementioned reports detailing the IA inflammation affiliated with CGD and CF, employing IL1R blockade restored LC3 phagolysosome formation in the monocytes from CGD patients [49] as well as in the macrophages from mice deficient in CFTR [50].

\section{Hypoxia}

A previous study employing 3 different models of IA (cyclophosphamide treatment, corticosteroid treatment, and gp91phox-deficient CGD mice) demonstrated hypoxia in the foci of innate inflammation and A. fumigatus organisms [64]. This observation suggests that both the host and A. fumigatus must adapt in order to survive in a low-
Table 1. List of reviewed innate immune factors

\begin{tabular}{|c|c|c|}
\hline Name & Gene & References \\
\hline NAPDH oxidase & $C y b b$ & 12 \\
\hline Myeloperoxidase & $M p o$ & 12 \\
\hline Lactoferrin & Ltf & 12 \\
\hline Protein kinase $\mathrm{C} \gamma$ & Prkcg & 14 \\
\hline LC3 & Map1lc3a & $49,50,62,63$ \\
\hline HIF-1 $\alpha$ & Hifla & 66,67 \\
\hline$\beta$-Defensin 1 & Defb & 69 \\
\hline Dectin-1 & Clec7a & $14,19,33-35,62$ \\
\hline Dectin-2 & Clec6a & 36,37 \\
\hline DC-SIGN & $C d 209$ & 16 \\
\hline CR3 & Itgam/ltgb2 & 12,14 \\
\hline TLR3 & TIr3 & 27 \\
\hline TLR5 & $\operatorname{TIr} 5$ & 28,29 \\
\hline TLR10 & $\operatorname{TIr} 10$ & 30 \\
\hline PTX3 & Ptx3 & $21,38,39,40$ \\
\hline M-ficolin & Fcn 1 & 41,42 \\
\hline L-ficolin & Fcn2 & 43 \\
\hline $\mathrm{H}$-ficolin & Fcn3 & 44 \\
\hline IL-1a & Illa & $19,47,67$ \\
\hline IL- $1 \beta$ & $I l 1 b$ & $19,32,45,47,48,67,69$ \\
\hline IL-1RA & Il1rn & $49,50,67$ \\
\hline IL-36a & $I l 36 a$ & 51 \\
\hline IL-36 $\gamma$ & $I l 36 g$ & 51 \\
\hline IL-37 & $\operatorname{Il} 37^{\circ}$ & 52 \\
\hline IL-17A & $I l 17 a$ & $19,53-55,59$ \\
\hline IL-22 & $I l 22$ & 58,59 \\
\hline G-CSF & Csf3 & 24 \\
\hline GM-CSF & Csf2 & 60 \\
\hline CXCR2 & Cxcr 2 & 19,67 \\
\hline CCR2 & Ccr 2 & 21 \\
\hline
\end{tabular}

oxygen environment. An example of A. fumigatus adaptation during hypoxia is the increase in hyphal cell wall thickness and surface-exposed $\beta$-glucan content [65]. This results in increased Dectin-1-mediated macrophage and neutrophil inflammatory responses. Hypoxia-inducible factor 1 (HIF-1)a is a host transcription factor that mediates multiple functions during periods of low oxygen. $A$. fumigatus has recently been shown to stabilize HIF-1a in the lung, a process interrupted by CT [66]. Mice with HIF$1 a$ deletion in myeloid cells rapidly succumb to IA as a result of impaired neutrophil recruitment to the lungs and enhanced neutrophil apoptosis [66]. A recent study documented that mice deficient in CXCR2 and those immunosuppressed with corticosteroids display defective clearance of A. fumigatus from the lungs in the presence of increased hypoxia and increased levels of proinflammatory cytokines, including IL- $1 \alpha$ and IL-1 $\beta$ [67]. To this end, treatment with the IL-1 blocking agent anakinra limited the de- 
Fig. 1. Neutrophils recognize A. fumigatus via multiple membrane-expressed (Dectin-1 and CR3) and soluble (PTX3) PRRs, that trigger innate antifungal responses against $A$. fumigatus conidia (lactoferrin) and hyphae (ROS and NETs).

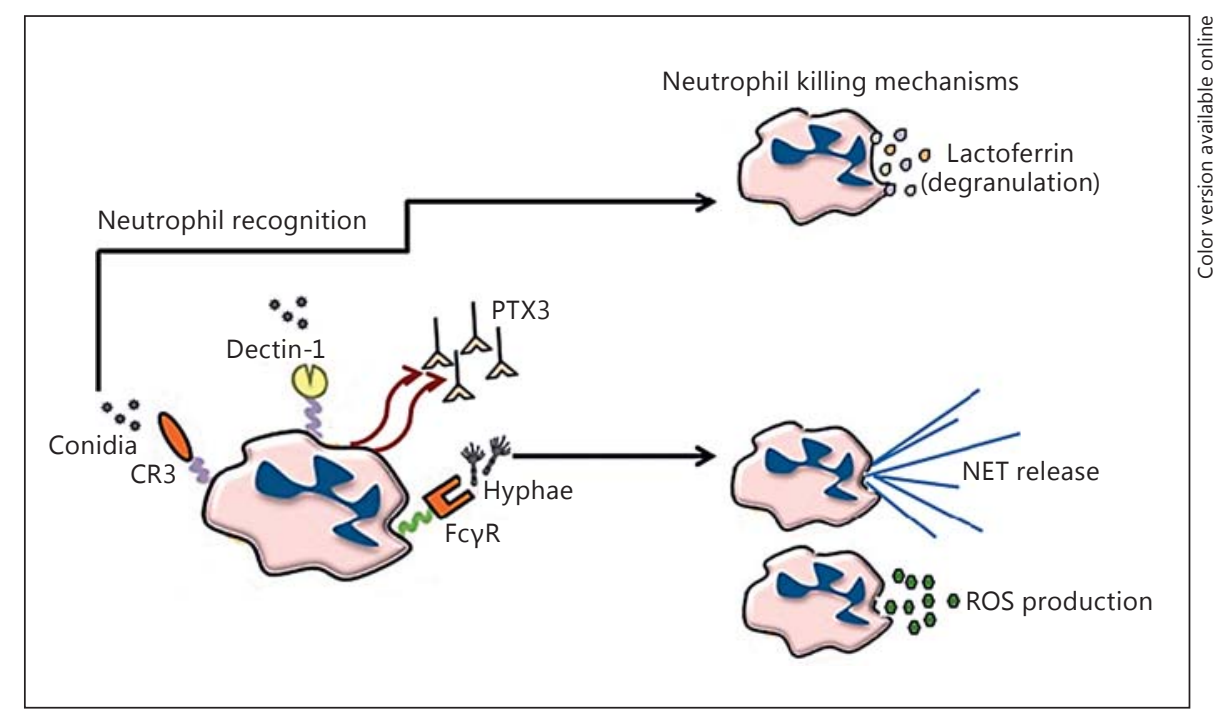

velopment of hypoxia and improved outcome during $A$. fumigatus infection in mice receiving $\mathrm{CT}$, but was not effective in CXCR2-deficient mice [67].

\section{Genome-Wide Association Studies}

With the advent of newer technologies, there has been renewed interest in further understanding the genes associated with risk of or susceptibility to IA. In a recent case-controlled study of nearly $800 \mathrm{immunocompromised}$ individuals, 149 of whom were diagnosed with IA, SNPs in IL-4R and IL-8 were associated with increased risk and those in IL-12B and IFN- $\gamma$ with decreased risk [68]. In fact, patients with the SNP in IFN- $\gamma$ were found to have better macrophage effector function against $A$. fumigatus and produced more IFN- $\gamma$ and TNF- $\alpha$. In another study that focused specifically on recipients of solid-organ transplants, genome-wide association study analysis led to the identification of IL- $1 \beta$ and $\beta$-defensin 1 as essential for limiting fungal colonization and/or infection [69]. Finally, a recent study examining genes in the NF- $\mathrm{KB}$ family found that, despite identifying an SNP in IRF4 that was associated with a 6 -fold increased risk of developing IA, this did not reach statistical significance [70].

\section{Conclusion}

Table 1 summarizes new findings in the area of innate host defense mechanisms during IA in the last 3-5 years. A better understanding of the genetic immunodeficiency that predisposes to fungal infections has paved the way for understanding aspects like how innate immune cells (such as neutrophils) recognize (via CR3 and PTX3) and kill $A$. fumigatus conidia (via lactoferrin) and hyphae (via ROS and NETs) (Fig. 1). New roles for TLR3 and TLR 5 have been identified and unappreciated roles for new innate cell types, such as inflammatory monocytes and eosinophils, have been discovered. The IL-1 family members IL- $1 \alpha$ and IL- $1 \beta$ are now recognized as central mediators of $A$. fumigatus clearance, yet they function in a negative role as drivers of unwanted inflammation in diseases such as CGD and CF. Finally, there is new recognition of processes such as autophagy and hypoxia that modulate innate immune responsiveness. With the rise in invasive fungal infections such as IA in a wide range of patients who are both immunocompetent and immunocompromised, it is extremely critical to identify how the mechanisms involved in the innate immune response work together to clear $A$. $f u$ migatus from the lungs. With a better understanding of the PRRs, cytokines, immune cells, and effector mechanisms involved in combating IA, we are provided with more in-depth knowledge of the potential candidates for developing therapies to boost the immune response and prevent or limit infection.

\section{Acknowledgements}

We sincerely thank Kristen Reeder, Matthew Godwin, and Joseph Mackel from the Steele Laboratory for critical reading of the manuscript. The Steele Laboratory is supported by grants HL122426 and HL136211 from the National Institutes of Health. 


\section{References}

1 Herbrecht R, Bories P, Moulin JC, Ledoux MP, Letscher-Bru V: Risk stratification for invasive aspergillosis in immunocompromised patients. Ann NY Acad Sci 2012;1272:23-30.

2 De Le Rosa GR, Champlin RE, Kontoyiannis DP: Risk factors for the development of invasive fungal infections in allogeneic blood and marrow transplant recipients. Transpl Infect Dis 2002;4:3-9.

3 Azie N, Neofytos D, Pfaller M, Meier-Kriesche HU, Quan SP, Horn D: The PATH (Prospective Antifungal Therapy) Alliance ${ }^{\circledR}$ registry and invasive fungal infections: update 2012. Diagn Microbiol Infect Dis 2012;73: 293-300.

4 Pappas PG, Alexander BD, Andes DR, Hadley S, Kauffman CA, Freifeld A, Anaissie EJ, Brumble LM, Herwaldt L, Ito J, Kontoyiannis DP, Lyon GM, Marr KA, Morrison VA, Park BJ, Patterson TF, Perl TM, Oster RA, Schuster MG, Walker R, Walsh TJ, Wannemuehler KA, Chiller TM: Invasive fungal infections among organ transplant recipients: results of the Transplant-Associated Infection Surveillance Network (TRANSNET). Clin Infect Dis 2010;50:1101-1111.

5 Kontoyiannis DP, Marr KA, Park BJ, Alexander BD, Anaissie EJ, Walsh TJ, Ito J, Andes DR, Baddley JW, Brown JM, Brumble LM, Freifeld AG, Hadley S, Herwaldt LA, Kauffman CA, Knapp K, Lyon GM, Morrison VA, Papanicolaou G, Patterson TF, Perl TM, Schuster MG, Walker R, Wannemuehler KA, Wingard JR, Chiller TM, Pappas PG: Prospective surveillance for invasive fungal infections in hematopoietic stem cell transplant recipients, 2001-2006: overview of the Transplant-Associated Infection Surveillance Network (TRANSNET) database. Clin Infect Dis 2010;50:1091-1100.

6 Doligalski CT, Benedict K, Cleveland AA, Park B, Derado G, Pappas PG, Baddley JW, Zaas DW, Harris MT, Alexander BD: Epidemiology of invasive mold infections in lung transplant recipients. Am J Transplant 2014; 14:1328-1333.

7 Meersseman W, Lagrou K, Maertens J, Wilmer A, Hermans G, Vanderschueren S, Spriet I, Verbeken E, Van Wijngaerden E: Galactomannan in brochoalveolar lavage fluid - a tool for diagnosing aspergillosis in intensive care unit patients. Am J Respir Crit Care Med 2008;177:27-34.

8 Trof RJ, Beishuizen A, Debets-Ossenkopp YJ, Girbes AR, Groeneveld AB: Management of invasive pulmonary aspergillosis in non-neutropenic critically ill patients. Intensive Care Med 2007;33:1694-1703.

9 Baddley JW, Stephens JM, Ji X, Gao X, Schlamm HT, Tarallo M: Aspergillosis in intensive care unit (ICU) patients: epidemiology and economic outcomes. BMC Infect Dis 2013;13:29.
10 Taccone FS, Van den Abeele AM, Bulpa P, Misset B, Meersseman W, Cardoso T, Paiva JA, Blasco-Navalpotro M, De Laere E, Dimopoulos G, Rello J, Vogelaers D, Blot SI: Epidemiology of invasive aspergillosis in critically ill patients: clinical presentation, underlying conditions, and outcomes. Crit Care 2015;19:7.

11 Schaffner A, Douglas H, Braude A: Selective protection against conidia by mononuclear and against mycelia by polymorphonuclear phagocytes in resistance to Aspergillus. Observations on these two lines of defense in vivo and in vitro with human and mouse phagocytes. J Clin Invest 1982;69:617-631.

12 Gazendam RP, van Hamme JL, Tool AT, Hoogenboezem M, van den Berg JM, Prins JM, Vitkov L, van de Veerdonk FL, van den Berg TK, Roos D, Kuijpers TW: Human neutrophils use different mechanisms to kill Aspergillus fumigatus conidia and hyphae: evidence from phagocyte defects. J Immunol 2016;196:1272-1283.

13 Jones CN, Dimisko L, Forrest K, Judice K, Poznansky MC, Markmann JF, Vyas JM, Irimia D: Human neutrophils are primed by chemoattractant gradients for blocking the growth of Aspergillus fumigatus. J Infect Dis 2016;213:465-475.

14 Li X, Cullere X, Nishi H, Saggu G, Durand E, Mansour MK, Tam JM, Song XY, Lin X, Vyas JM, Mayadas T: PKC-delta activation in neutrophils promotes fungal clearance. J Leukoc Biol 2016;100:581-588.

15 Park SJ, Burdick MD, Brix WK, Stoler MH, Askew DS, Strieter RM, Mehrad B: Neutropenia enhances lung dendritic cell recruitment in response to Aspergillus via a cytokine-tochemokine amplification loop. J Immunol 2010;185:6190-6197.

16 Park SJ, Burdick MD, Mehrad B: Neutrophils mediate maturation and efflux of lung dendritic cells in response to Aspergillus fumigatus germ tubes. Infect Immun 2012;80:17591765.

17 Kalleda N, Amich J, Arslan B, Poreddy S, Mattenheimer K, Mokhtari Z, Einsele H, Brock M, Heinze KG, Beilhack A: Dynamic immune cell recruitment after murine pulmonary Aspergillus fumigatus infection under different immunosuppressive regimens. Front Microbiol 2016;7:1107.

18 Quintin J, Saeed S, Martens JH, GiamarellosBourboulis EJ, Ifrim DC, Logie C, Jacobs L, Jansen T, Kullberg BJ, Wijmenga C, Joosten LA, Xavier RJ, van der Meer JW, Stunnenberg HG, Netea MG: Candida albicans infection affords protection against reinfection via functional reprogramming of monocytes. Cell Host Microbe 2012;12:223-232.

19 Savers A, Rasid O, Parlato M, Brock M, Jouvion G, Ryffel B, Cavaillon JM, Eberl G, Ibrahim-Granet $O$ : Infection-mediated priming of phagocytes protects against lethal secondary Aspergillus fumigatus challenge. PLoS One 2016;11:e0153829.
20 Shah A, Kannambath S, Herbst S, Rogers A, Soresi S, Carby M, Reed A, Mostowy S, Fisher MC, Shaunak S, Armstrong-James DP: Calcineurin orchestrates lateral transfer of Aspergillus fumigatus during macrophage cell death. Am J Respir Crit Care Med 2016;194: 1127-1139.

21 Espinosa V, Jhingran A, Dutta O, Kasahara S, Donnelly R, Du P, Rosenfeld J, Leiner I, Chen CC, Ron Y, Hohl TM, Rivera A: Inflammatory monocytes orchestrate innate antifungal immunity in the lung. PLoS Pathog 2014; 10:e1003940.

22 Lilly LM, Scopel M, Nelson MP, Burg AR, Dunaway CW, Steele C: Eosinophil deficiency compromises lung defense against Aspergillus fumigatus. Infect Immun 2014;82:1315-1325.

23 Cohen NR, Tatituri RV, Rivera A, Watts GF, Kim EY, Chiba A, Fuchs BB, Mylonakis E, Besra GS, Levitz SM, Brigl M, Brenner MB: Innate recognition of cell wall $\beta$-glucans drives invariant natural killer T cell responses against fungi. Cell Host Microbe 2011;10: 437-450.

24 Beitzen-Heineke A, Bouzani M, Schmitt AL, Kurzai O, Hunniger K, Einsele H, Loeffler J: Human invariant natural killer T cells possess immune-modulating functions during Aspergillus infection. Med Mycol 2016;54:169-176.

25 Kesh S, Mensah NY, Peterlongo P, Jaffe D, Hsu K, Van den Brink M, O’Reilly R, Pamer E, Satagopan J, Papanicolaou GA: TLR1 and TLR6 polymorphisms are associated with susceptibility to invasive aspergillosis after allogeneic stem cell transplantation. Ann NY Acad Sci 2005;1062:95-103.

26 Bochud PY, Chien JW, Marr KA, Leisenring WM, Upton A, Janer M, Rodrigues SD, Li S, Hansen JA, Zhao LP, Aderem A, Boeckh M: Toll-like receptor 4 polymorphisms and aspergillosis in stem cell transplantation. N Engl J Med 2008;359:1766-1777.

27 Carvalho A, De LA, Bozza S, Cunha C, D’Angelo C, Moretti S, Perruccio K, Iannitti RG, Fallarino F, Pierini A, Latge JP, Velardi A, Aversa F, Romani L: TLR3 essentially promotes protective class I-restricted memory $\mathrm{CD}^{+} \mathrm{T}$-cell responses to Aspergillus fumigatus in hematopoietic transplanted patients. Blood 2012;119:967-977.

28 Rodland EK, Ager-Wick E, Halvorsen B, Müller F, Frøland SS: Toll-like receptor 5 (TLR5) may be involved in the immunological response to Aspergillus fumigatus in vitro. Med Mycol 2011;49:375-379.

29 Grube M, Loeffler J, Mezger M, Krüger B, Echtenacher B, Hoffmann P, Edinger M, Einsele H, Andreesen R, Holler E: TLR5 stop codon polymorphism is associated with invasive aspergillosis after allogeneic stem cell transplantation. Med Mycol 2013;51:818-825. 
30 Smith NL, Hankinson J, Simpson A, Denning DW, Bowyer P: Reduced expression of TLR3, TLR10 and TREM1 by human macrophages in chronic cavitary pulmonary aspergillosis, and novel associations of VEGFA, DENND1B and PLAT. Clin Microbiol Infect 2014; 20:O960-O968.

31 Wagener J, Malireddi RK, Lenardon MD, Koberle M, Vautier S, MacCallum DM, Biedermann T, Schaller M, Netea MG, Kanneganti TD, Brown GD, Brown AJ, Gow NA: Fungal chitin dampens inflammation through IL-10 induction mediated by NOD2 and TLR9 activation. PLoS Pathog 2014; 10:e1004050.

32 Becker K L, Aimanianda V, Wang X, Gresnigt MS, Ammerdorffer A, Jacobs CW, Gazendam RP, Joosten LA, Netea MG, Latge JP, van de Veerdonk FL: Aspergillus cell wall chitin induces anti- and proinflammatory cytokines in human PBMCs via the Fc- $\gamma$ receptor/Syk/ PI3K pathway. MBio 2016;7:e01823.

33 Sun WK, Lu X, Li X, Sun QY, Su X, Song Y, Sun HM, Shi Y: Dectin-1 is inducible and plays a crucial role in Aspergillus-induced innate immune responses in human bronchial epithelial cells. Eur J Clin Microbiol Infect Dis 2012;31:2755-2764.

34 Branzk N, Lubojemska A, Hardison SE, Wang Q, Gutierrez MG, Brown GD, Papayannopoulos V: Neutrophils sense microbe size and selectively release neutrophil extracellular traps in response to large pathogens. Nat Immunol 2014;15:1017-1025.

35 Rieber N, Singh A, Öz H, Carevic M, Bouzani M, Amich J, Ost M, Ye Z, Ballbach M, Schäfer I, Mezger M, Klimosch SN, Weber AN, Handgretinger R, Krappmann S, Liese J, Engeholm M, Schüle R, Salih HR, Marodi L, Speckmann C, Grimbacher B, Ruland J, Brown GD, Beilhack A, Loeffler J, Hartl D: Pathogenic fungi regulate immunity by inducing neutrophilic myeloid-derived suppressor cells. Cell Host Microbe 2015;17:507-514.

36 Taylor PR, Roy S, Leal SM Jr, Sun Y, Howell SJ, Cobb BA, Li X, Pearlman E: Activation of neutrophils by autocrine IL-17A-IL-17RC interactions during fungal infection is regulated by IL-6, IL-23, ROR $\gamma$ t and dectin-2. Nat Immunol 2014;15:143-151.

37 Loures FV, Rohm M, Lee CK, Santos E, Wang JP, Specht CA, Calich VL, Urban CF, Levitz SM: Recognition of Aspergillus fumigatus hyphae by human plasmacytoid dendritic cells is mediated by dectin- 2 and results in formation of extracellular traps. PLoS Pathog 2015; 11:e1004643.

38 Cunha C, Aversa F, Lacerda JF, Busca A, Kurzai O, Grube M, Löffler J, Maertens JA, Bell AS, Inforzato A, Barbati E, Almeida B, Santos e Sousa P, Barbui A, Potenza L, Caira M, Rodrigues F, Salvatori G, Pagano L, Luppi M, Mantovani A, Velardi A, Romani L, Carvalho A: Genetic PTX3 deficiency and aspergillosis in stem-cell transplantation. $\mathrm{N}$ Engl J Med 2014;370:421-432.
39 Bozza S, Campo S, Arseni B, Inforzato A, Ragnar L, Bottazzi B, Mantovani A, Moretti S, Oikonomous V, De Santis R, Carvalho A, Salvatori $\mathrm{G}$, Romani $\mathrm{L}$ : PTX3 binds MD-2 and promotes TRIF-dependent immune protection in aspergillosis. J Immunol 2014;193: 2340-2348.

40 Zelante T, Wong AY, Mencarelli A, Foo S, Zolezzi F, Lee B, Poidinger M, Ricciardi-Castagnoli P, Fric J: Impaired calcineurin signaling in myeloid cells results in downregulation of pentraxin-3 and increased susceptibility to aspergillosis. Mucosal Immunol 2016, E-pub ahead of print.

41 Bidula S, Kenawy H, Ali YM, Sexton D, Schwaeble WJ, Schelenz S: Role of ficolin-A and lectin complement pathway in the innate defense against pathogenic Aspergillus species. Infect Immun 2013;81:1730-1740.

42 Bidula S, Sexton DW, Schelenz S: Serum opsonin ficolin-A enhances host-fungal interactions and modulates cytokine expression from human monocyte-derived macrophages and neutrophils following Aspergillus fumigatus challenge. Med Microbiol Immunol 2016; 205:133-142.

43 Bidula S, Sexton DW, Abdolrasouli A, Shah A, Reed A, Armstrong-James D, Schelenz S: The serum opsonin L-ficolin is detected in lungs of human transplant recipients following fungal infections and modulates inflammation and killing of Aspergillus fumigatus. J Infect Dis 2015;212:234-246.

44 Bidula S, Sexton DW, Yates M, Abdolrasouli A, Shah A, Wallis R, Reed A, ArmstrongJames D, Schelenz S: $\mathrm{H}$-ficolin binds Aspergillus fumigatus leading to activation of the lectin complement pathway and modulation of lung epithelial immune responses. Immunology 2015;146:281-291.

45 Genster N, Praestekjaer CE, Rosbjerg A, Pilely K, Cowland JB, Garred P: Ficolins promote fungal clearance in vivo and modulate the inflammatory cytokine response in host defense against Aspergillus fumigatus. J Innate Immun 2016;8:579-588.

46 Bellocchio S, Montagnoli C, Bozza S, Gaziano R, Rossi G, Mambula SS, Vecchi A, Mantovani A, Levitz SM, Romani L: The contribution of toll-like/IL-1 receptor superfamily to innate and adaptive immunity to fungal pathogens in vivo. J Immunol 2004;172: 3059-3069.

47 Caffrey AK, Lehmann MM, Zickovich JM, Espinosa V, Shepardson KM, Watschke CP, Hilmer KM, Thammahong A, Barker BM, Rivera $A$, Cramer RA, Obar JJ: IL-1a signaling is critical for leukocyte recruitment after pulmonary Aspergillus fumigatus challenge. PLoS Pathog 2015;11:e1004625.

48 Karki R, Man SM, Malireddi RK, Gurung P, Vogel P, Lamkanfi M, Kanneganti TD: Concerted activation of the AIM2 and NLRP3 inflammasomes orchestrates host protection against Aspergillus infection. Cell Host Microbe $2015 ; 17: 357-368$.
49 de Luca A, Smeekens SP, Casagrande A, Iannitti R, Conway KL, Gresnigt MS, Begun J, Plantinga TS, Joosten LA, van der Meer JW, Chamilos G, Netea MG, Xavier RJ, Dinarello CA, Romani L, van de Veerdonk FL: IL-1 receptor blockade restores autophagy and reduces inflammation in chronic granulomatous disease in mice and in humans. Proc Natl Acad Sci USA 2014;111:3526-3531.

50 Iannitti RG, Napolioni V, Oikonomou V, de Luca A, Galosi C, Pariano M, Massi-Benedetti C, Borghi M, Puccetti M, Lucidi V, Colombo C, Fiscarelli E, Lass-Flörl C, Majo F, Cariani L, Russo M, Porcaro L, Ricciotti G, Ellemunter H, Ratclif L, De Benedictis FM, Talesa VN, Dinarello CA, van de Veerdonk FL, Romani L: IL-1 receptor antagonist ameliorates inflammasome-dependent inflammation in murine and human cystic fibrosis. Nat Commun 2016;7:10791.

51 Gresnigt MS, Rösler B, Jacobs CW, Becker KL, Joosten LA, van der Meer JW, Netea MG, Dinarello CA, van de Veerdonk FL: The IL-36 receptor pathway regulates Aspergillus fumigatus-induced Th1 and Th17 responses. Eur J Immunol 2013;43:416-426.

52 Moretti S, Bozza S, Oikonomou V, Renga G Casagrande A, Iannitti RG, Puccetti M, Garlanda C, Kim S, Li S, van de Veerdonk FL, Dinarello CA, Romani L: IL-37 inhibits inflammasome activation and disease severity in murine aspergillosis. PLoS Pathog 2014; 10:e1004462.

53 Taylor PR, Leal SM Jr, Sun Y, Pearlman E: Aspergillus and Fusarium corneal infections are regulated by Th17 cells and IL-17-producing neutrophils. J Immunol 2014;192:3319-3327.

54 Taylor PR, Roy S, Meszaros EC, Sun Y, Howell SJ, Malemud CJ, Pearlman E: JAK/STAT regulation of Aspergillus fumigatus corneal infections and IL-6/23-stimulated neutrophil, IL-17, elastase, and MMP9 activity. J Leukoc Biol 2016;100:213-222.

55 Schlitzer A, McGovern N, Teo P, Zelante T, Atarashi K, Low D, Ho AW, See P, Shin A, Wasan PS, Hoeffel G, Malleret B, Heiseke A, Chew S, Jardine L, Purvis HA, Hilkens CM, Tam J, Poidinger M, Stanley ER, Krug AB, Renia L, Sivasankar B, Ng LG, Collin M, Ricciardi-Castagnoli P, Honda K, Haniffa M, Ginhoux F: IRF4 transcription factor-dependent CD11b+ dendritic cells in human and mouse control mucosal IL-17 cytokine responses. Immunity 2013;38:970-983.

56 Gessner M A, Werner JL, Lilly LM, Nelson MP, Metz AE, Dunaway CW, Chan YR, Ouyang W, Brown GD, Weaver CT, Steele C: Dectin-1-dependent interleukin-22 contributes to early innate lung defense against Aspergillus fumigatus. Infect Immun 2012;80:410417.

57 Lilly LM, Gessner MA, Dunaway CW, Metz AE, Schwiebert L, Weaver CT, Brown GD, Steele C: The $\beta$-glucan receptor dectin-1 promotes lung immunopathology during fungal allergy via IL-22. J Immunol 2012;189:36533660 . 
58 Gresnigt MS, Becker KL, Smeekens SP, Jacobs CW, Joosten LA, van der Meer JW, Netea MG, van de Veerdonk FL: Aspergillus fumigatus-induced IL-22 is not restricted to a specific Th cell subset and is dependent on complement receptor 3. J Immunol 2013;190: 5629-5639.

59 Chan YR, Chen K, Duncan SR, Lathrop KL, Latoche JD, Logar AJ, Pociask DA, Wahlberg BJ, Ray P, Ray A, Pilewski JM, Koll JK: Patients with cystic fibrosis have inducible IL17+IL-22+ memory cells in lung draining lymph nodes. J Allergy Clin Immunol 2013; 131:1117-1129, 1129.

60 Kasahara S, Jhingran A, Dhingra S, Salem A, Cramer RA, Hohl TM: Role of granulocytemacrophage colony-stimulating factor signaling in regulating neutrophil antifungal activity and the oxidative burst during respiratory fungal challenge. J Infect Dis 2016;213: 1289-1298.

61 Faro-Trindade I, Willment JA, Kerrigan AM, Redelinghuys P, Hadebe S, Reid DM, Srinivasan N, Wainwright H, Lang DM, Steele C, Brown GD: Characterisation of innate fungal recognition in the lung. PLoS One 2012;7: e35675.

62 Kyrmizi I, Gresnigt MS, Akoumianaki T, Samonis G, Sidiropoulos P, Boumpas D, Netea MG, van de Veerdonk FL, Kontoyiannis DP, Chamilos G: Corticosteroids block autophagy protein recruitment in Aspergillus fumigatus phagosomes via targeting dectin-1/Syk kinase signaling. J Immunol 2013;191:1287-1299.
63 Chamilos G, Akoumianaki T, Kyrmizi I, Brakhage A, Beauvais A, Latge JP: Melanin targets LC3-associated phagocytosis (LAP): a novel pathogenetic mechanism in fungal disease. Autophagy 2016;12:888-889.

64 Grahl N, Puttikamonkul S, Macdonald JM Gamcsik MP, Ngo LY, Hohl TM, Cramer RA: In vivo hypoxia and a fungal alcohol dehydrogenase influence the pathogenesis of invasive pulmonary aspergillosis. PLoS Pathog 2011;7: e1002145.

65 Shepardson KM, Ngo LY, Aimanianda V, Latge JP, Barker BM, Blosser SJ, Iwakura Y, Hohl TM, Cramer RA: Hypoxia enhances innate immune activation to Aspergillus fumigatus through cell wall modulation. Microbes Infect 2013;15:259-269.

66 Shepardson KM, Jhingran A, Caffrey A, Obar JJ, Suratt BT, Berwin BL, Hohl TM, Cramer RA: Myeloid derived hypoxia inducible factor 1-alpha is required for protection against pulmonary Aspergillus fumigatus infection. PLoS Pathog 2014;10:e1004378.

67 Gresnigt MS, Rekiki A, Rasid O, Savers A, Jouvion G, Dannaoui E, Parlato M, Fitting C, Brock M, Cavaillon JM, van de Veerdonk FL, Ibrahim-Granet O: Reducing hypoxia and inflammation during invasive pulmonary aspergillosis by targeting the interleukin-1 receptor. Sci Rep 2016;6:26490.
68 Lupianez CB, Canet LM, Carvalho A, Alcazar-Fuoli L, Springer J, Lackner M, SeguraCatena J, Comino A, Olmedo C, Rios R, Fernandez-Montoya A, Cuenca-Estrella $\mathrm{M}$, Solano C, Lopez-Nevot MA, Cunha C, Oliveira-Coelho A, Villaescusa T, Fianchi L, Aguado JM, Pagano L, Lopez-Fernandez E, Potenza L, Luppi M, Lass-Flörl C, Loeffler J, Einsele H, Vazquez L, Jurado M, Sainz J: Polymorphisms in host immunity-modulating genes and risk of invasive aspergillosis: results from the AspBIOmics Consortium. Infect Immun 2015;84:643-657.

69 Wojtowicz A, Gresnigt MS, Lecompte T, Bibert S, Manuel O, Joosten LA, Rueger S, Berger C, Boggian K, Cusini A, Garzoni C, Hirsch HH, Weisser M, Mueller NJ, Meylan PR, Steiger J, Kutalik Z, Pascual M, van Delden C, van de Veerdonk FL, Bochud PY: IL1B and DEFB1 polymorphisms increase susceptibility to invasive mold infection after solid-organ transplantation. J Infect Dis 2015;211:16461657.

70 Lupianez CB, Villaescusa MT, Carvalho A, Springer J, Lackner M, Sanchez-Maldonado JM, Canet LM, Cunha C, Segura-Catena J, Alcazar-Fuoli L, Solano C, Fianchi L, Pagano L, Potenza L, Aguado JM, Luppi M, Cuenca-Estrella M, Lass-Florl C, Einsele H, Vazquez L, Rios-Tamayo R, Loeffle J, Jurado M, Sainz J: Common genetic polymorphisms within NFkB-related genes and the risk of developing invasive aspergillosis. Front Microbiol 2016;7:1243 